\title{
Effects of diets containing hemp seeds or hemp cake on fatty acid composition and oxidative stability of sheep milk
}

\author{
D. Mierliță \\ University of Oradea, Department of Animal Science, Oradea City, 410087, Romania
}

(Received 21 December 2017; Accepted 22 January 2018; First published online 23 February 2018)

Copyright resides with the authors in terms of the Creative Commons Attribution 4.0 South African Licence.

See: http://creativecommons.org/licenses/by/4.0/za

Condition of use: The user may copy, distribute, transmit and adapt the work, but must recognise the authors and the South African Journal of Animal Science.

\begin{abstract}
High levels of polyunsaturated fatty acids (PUFAs) are desirable in milk for its nutritional quality, but make it vulnerable to oxidation. The aim of this trial was to assess the effects of dietary intake of hemp (seeds or cake) on milk production, fatty acid (FA) profile, and oxidative stability when sheep diet included a source rich in PUFAs. The control diet (C), which was composed of hay-based rations and completed with mixed concentrate, was compared with two experimental diets that were designed to provide the same amount of fat via hemp seed $(180 \mathrm{~g} / \mathrm{d})$ (HS diet) or hempseed cake $(480 \mathrm{~g} / \mathrm{d})$ ( $\mathrm{HC}$ diet). The hemp was determined to have significantly increased the yields of milk, energy-corrected milk (ECM), fat corrected milk (FCM) (6.5\%), protein corrected milk (PCM) $(5.8 \%)$ and milk fat. The hemp generated a greater proportion of n-3 FA, notably $\alpha$-linolenic acid (ALA), which increased by $49-66 \%$. The addition of hemp also led to an increase in C18:1 t11 (vaccenic acid (VA)) and conjugated linoleic acids (CLA), particularly isomer $c 9, t 11$ CLA (rumenic acid (RA)). The HC group showed a greater content of milk ALA and VA and tended to show a greater content of $c 9, t 11$ CLA than the HS group. The atherogenic index (AI), thrombogenic index (TI), $n-6 / n-$ 3 FA ratio and hypocholesterolemic/Hypercholesterolemic $(h / H)$ ratio suggest that hemp could be useful in improving milk quality. The results obtained in this study suggest that the inclusion of hempseed cake appears to be more effective in ameliorating these indices than hemp seed. The author determined the concentration of fat-soluble antioxidant (tocopherol and retinol) by high performance liquid chromatography (HPLC), and assessed the total antioxidant capacity (TAC) by measuring the ABTS (2,2'-azinobis-3ethylbenzothiazoline-6-sulfonic acid) scavenging capacity and degree of oxidative degradation of lipids using the classical test based on the concentration of malondialdehyde (MDA). The TAC was higher in the milk of the $\mathrm{HS}$ and $\mathrm{HC}$ groups compared with $\mathrm{C}$, being in direct correlation with the higher concentration of $\alpha$ tocopherol of milk and lower concentration of MDA, the extent of the change being greatest for the animals fed the HS diet. Therefore, hemp seeds and hempseed cake appear to be ideal supplements for improving the FA profile and health lipid indices and preventing lipid oxidation in raw milk.
\end{abstract}

Keywords: $\alpha$-linolenic acid, $\alpha$-tocopherol, antioxidant activity, atherogenicity index, malondialdehyde

\# Corresponding author: dadi.mierlita@yahoo.com

\section{Introduction}

There is growing interest in increasing the PUFA content in milk fat and improving its nutritional quality. The occurrence of PUFAs such as n-3 FAs and CLA (in particular isomer c9,t11 CLA) in food is of particular interest, thanks to their health-promoting properties. The n-3 FAs, especially ALA (C18:3 n-3), eicosapentaenoic acid (EPA) (C20:5 n-3), and docosahexaenoic acid (DHA) (C22:6n-3), can reduce the risk of cardiovascular diseases (Simopoulus, 1991). In experimental animals, c9,t11 CLA (RA) has proved to possess anti-cancer and anti-atherosclerotic effects and anti-obesity activities (Mills et al., 2011).

Diet is the most important factor that influences milk FA composition in dairy ewes. To increase the concentration of PUFAs in milk, sources of unsaturated plant lipids, such as linseed, soybean, safflower, and sunflower could be included successfully in the diet (Nudda et al., 2014). In a recent work, the inclusion of 
hemp seed, as a source of PUFAs, especially ALA, in the diet of dairy ewes was effective in improving the milk FA profile by decreasing the concentration of saturated FAs (SFAs) and the $n-6 / n-3 F A$ ratio, and increasing the amount of the trans-vaccenic acid (C18:1 t11, VA), ALA, CLA, EPA, and DHA concentrations in milk fat (Mierliță, 2016).

Hemp, Cannabis sativa L., was grown for fibre and seed production in the Nordic countries, but was prohibited because of a high narcotic substance (delta-9-tetrahydrocannabinol (THC)) content. In 2003, hemp varieties with low concentrations of THC were again allowed to be grown in the European Union (EU Council Directive, 2003) for fibre and oil production. Currently in the EU, only cultivars with less than $0.2 \%$ THC, as described in Council Regulation (EC) No 1420/98, are permitted. In 2012, the hemp cultivar Armanca, which is used in this study, was recorded in Romania as a variety utilized for oil seed production. Hemp seeds belonging to this variety have high nutritional value, and are used for human consumption and animal feeding (Mihoc et al., 2012).

The disadvantage of milk enriched with PUFAs is the possibility of oxidation owing to its high content of double-bonded molecules, which are prone to oxidation (Puppel et al., 2012). The delicate balance between anti- and pro- oxidative processes in milk is influenced by factors such as ruminant nutrition, degree of unsaturated FAs (UFAs), the contents of transition metal ions and of antioxidants such as tocopherols and carotenoids (Havemose et al., 2006). Havemose et al. (2006) proposed that an increase in ALA contributed to the accumulation of lipid peroxides in milk.

Hemp is grown for fibre or for seed, which is rich in long-chain UFAs. From the hemp seeds, oils with FA profiles favourable to human health are extracted for food and cosmetic purposes, and the remaining hempseed cake can be used as animal feed (Hessle et al., 2008). About $80 \%$ of hemp seed oil consists of PUFAs, which are rich in two essential FAs, namely LA (18:2 n-6) and ALA. As a comparison, the ALA fractions of hemp seed, soybean and sunflower seed have been determined at $19.7 \%, 7.8 \%$ and $0.5 \%$ respectively, as reviewed by Dubois et al. (2007). The ALA yield of hemp per hectare was shown to equal that of flax (Dubois et al., 2007).

Hemp seeds contain tocopherols, which increase the oxidative stability of dark and white chicken meat significantly (Lin et al., 1989). Hemp seeds were utilized successfully to manipulate the FA profile in bovine adipose tissue (Gibb et al., 2005), eggs (Silversides \& Lefrancois, 2005), and sheep milk (Mierliță, 2016).

One potential opportunity for the use of hemp as a feed ingredient relates to the relatively high level of ALA (17-19\%) (Parker et al., 2003), compared with other vegetable oils (<9\%), with the notable exception being flax. Because flaxseed has been used successfully in the diets of ewes to produce n- 3 enriched milk (Zhang et al., 2006), the level of ALA in hemp seeds or cake might provide additional options to produce $n-3$ sheep milk.

Currently, there has been not enough research into the effects of hemp inclusion in animal diets and its nutritive and antioxidant efficacy in animals (Konca et al., 2014). Consequently, the current study was designed to assess the effect dietary intake of hemp seeds or cake on milk production and the FA profile of milk. As stated, high levels of PUFAs in milk are desirable for its nutritional quality, but make it vulnerable to oxidation. Accordingly, the secondary objective of the study was to examine the oxidative stability of milk when sheep diet included a source that was rich in PUFAs.

\section{Materials and Methods}

The experiment was conducted at a dairy sheep farm in the west of Romania from February to April 2016. Thirty Turcana dairy ewes were selected to form three groups, which were balanced for milk production $(0.75 \pm 0.02 \mathrm{~kg} / \mathrm{d}$ per head), bodyweight $(\mathrm{BW})(44.6 \pm 0.8 \mathrm{~kg})$, dry matter intake $(2.12 \pm 0.04$ $\mathrm{kg} / \mathrm{d}$ ), and number of lactations (2-3 lactations). Groups were randomly assigned to three dietary treatments consisting of a control diet composed of hay and completed with concentrates (high-energy concentrate and sunflower meal) and two experimental diets designed to provide the same amount of fat via hemp seed (180 $\mathrm{g} / \mathrm{d})$ ( $\mathrm{HS}$ diet) or hempseed cake $(480 \mathrm{~g} / \mathrm{d})(\mathrm{HC}$ diet). The diets were isoenergetic and isonitrogenous.

The hemp seeds (Cannabis sativa L., cv. Armanca variety for oil) were cold-pressed by a commercial oil producer, thus obtaining hempseed cake. Hemp seed and hempseed cake were supplied in quantities calculated to provide the ewes with the same amounts of PUFAs, that is, around $70 \mathrm{~g} / \mathrm{ewe}$ per day (55 $\mathrm{g}$ PUFA). The diets consisted of $900 \mathrm{~g}$ grass hay and $500 \mathrm{~g}$ alfalfa hay/ewe per day. The energy concentrate and sunflower meal were then adjusted to cover energy and nitrogen requirements: hemp seed was added as a replacement for the energy concentrate (corn and barley), and hempseed cake was added as a replacement for part of the sunflower meal and the energy concentrate (Hurtaud \& Peyraud, 2007). Ewes received supplements of $30 \mathrm{~g} / \mathrm{d}$ of mineral mix to cover mineral requirements. The hemp seed and cake were mixed carefully with the mixed concentrate meal.

The study lasted 10 weeks, with a two-week adaptation period and an eight-week experimental period. Forage samples were collected twice weekly and combined into one sample per week. All the forage 
samples collected were freeze-dried and ground through a 1-mm screen using a Wiley mill (Thomas Wiley, Philadelphia, PA). Samples were analysed for dry matter (DM) (ISO, 1999), neutral detergent fibre (NDF) and acid detergent fibre (ADF) (Van Soest et al., 1991) on a fibre analyser (Ankom Technology, Fairport, NY), extract ether (EE) (Soxhlet method, AOAC, 1996) and nitrogen (N) (Kjeldahl technique) (Vapodest Distillation Systems - Gerhardt; AOAC International, 1996). Samples of forage $(n=4)$ that were collected to determine the FA profile were stored immediately at $-20^{\circ} \mathrm{C}$, and later lyophilized and kept until analysis.

Milk samples were taken from each ewe and stored at $4{ }^{\circ} \mathrm{C}$ with a preservative (bronopol-B2) until analysis for protein, fat, and lactose. Protein, fat, and lactose concentrations in the milk samples were analysed by infrared spectrophotometry (Bentley model 2000; Bentley Instrument Inc., Chaska, MN).

Individual morning milk samples were combined weekly and stored at $-20{ }^{\circ} \mathrm{C}$ until analysis. Milk samples $(200 \mathrm{~mL}$ milk) collected in the last four weeks of the trial were divided into two parts. One was used to analyse milk FA composition and the other to analyse fat-soluble antioxidant content ( $\alpha$-tocopherol and retinol), TAC, and levels of MDA, a degradation product of lipid peroxidation. Milk samples were kept in 100 $\mathrm{mL}$ containers and protected from light.

Milk fat was obtained by centrifugation as described by Murphy et al. (1995) and FAs were methylated according to method 5509 of ISO (1978) using $\mathrm{KOH} /$ methanol and n-heptane. Fatty acid methyl esters (FAMES) were quantified by gas chromatography using a Varian GC 3600 equipped with FID and a fused silica capillary column (SP 2560 Supelco), $100 \mathrm{~m} \times 0.25 \mathrm{~mm}$ i.d., film thickness $0.20 \mu \mathrm{m}$. Helium was used as the carrier gas at a flow rate of $1 \mathrm{~mL} / \mathrm{min}$. The split ratio was $1: 100$. The oven temperature was programmed at $90{ }^{\circ} \mathrm{C}$ and held for $1.50 \mathrm{~min}$, then increased to $210^{\circ} \mathrm{C}$ at a rate of $9{ }^{\circ} \mathrm{C} / \mathrm{min}$, held at this temperature for $25 \mathrm{~min}$, then increased to $230^{\circ} \mathrm{C}$ at $15^{\circ} \mathrm{C} / \mathrm{min}$, and held for $7 \mathrm{~min}$. The temperatures of the injector and the detector were set at $270^{\circ} \mathrm{C}$. Fatty acid identification was based on external standards, and calculation of the distribution was based on the area of each FA ester corrected for the response factors for the individual FA. Internal standards were used to determine the percentage of recovery. The CLA isomers reported are $c 9, t 11$ CLA and $t 10, c 12$ CLA. The percentage of each FA was calculated by dividing the area under the FA peak by the sum of the areas under total reported FA peaks.

Determination of vitamins was done by HPLC of the extracts obtained from milk samples. Extraction of fat-soluble vitamins was done with a mixture of diethyl ether and petroleum ether (1:1), in aliquots of $20 \mathrm{~mL}$. The ether phase, after separation, was saponified with methanolic $\mathrm{KOH}$ solution (10\%), after which vitamins were extracted in hexane, washed with water in a separator funnel, and evaporated to dryness. The determination of retinol was conducted in a first stage curve standard using all-trans-retinol solutions (10-80 $\mathrm{mg} / \mathrm{mL}$ ). Standard solutions (Sigma) and samples were injected into a system (Parkin-Elmer LC-295), equipped with Altech C18 column (length $15 \mathrm{~cm}, 4.6 \mathrm{~mm}$ internal diameter and particle size $3 \mu \mathrm{m}$ ). The mobile phase consisted of acetonitrile/methanol (85:15), with the addition of 2-propanol (30\%) after eight min (Mierliță et al., 2017).

The dosage tocopherol was done using the same analysis conducted to extract retinol. After evaporation of the hexane phase, separation of the tocopherol was by HPLC using the column with characteristics described above. The mobile phase for the various tocopherols was acetonitrile : methanol (85 : 15)/isopropanol 90/10 (Mierlita et al., 2017). Tocopherol analysis in hemp samples was performed in the same way as in the milk samples. Instead of $2 \mathrm{~mL}$ milk, $0.4 \mathrm{~g}$ hemp seed or hempseed cake was taken to start the analysis. The concentrations of $\alpha-, \gamma$, and $\delta$-tocopherol in the samples were calculated with external standards (Sigma-Aldrich, USA) through a linear regression from known standards.

Determination of TAC of milk samples was done by Trolox® equivalent antioxidant capacity assay, which is based on the scavenging of the 2,2'-azinobis-(3-ethylbenzothiazoline-6-sulfonic acid) (ABTS ${ }^{+}$) (Sigma-Aldrich, St. Louis, USA) radical anion (ABTS) converted into a colourless product. The ABTS was dissolved in distilled water to a $7 \mathrm{mM}$ concentration. $\mathrm{ABTS}^{+}$was produced by reacting ABTS stock solution with $2.45 \mathrm{mM}$ potassium persulfate and allowing the mixture to stand in the dark at room temperature for 12 16 hours before use. The ABTS stock solution was diluted with saline phosphate buffer $(0.15 \mathrm{M}, 5 \mathrm{mM}$ phosphate, $\mathrm{pH} 6.7$ ) to obtain an absorbance of $0.70 \pm 0.02$ at $730 \mathrm{~nm}$. After adding $0.5 \mathrm{~mL}$ of various concentrations of Trolox ${ }^{\circledR}(0-20 \mu \mathrm{M})$ or milk samples to $2.0 \mathrm{~mL}$ of diluted $\mathrm{ABTS}^{+}$(working solution), the absorbance was read at $730 \mathrm{~nm}$ after 10 minutes at $25^{\circ} \mathrm{C}$ (Mierlita \& Vicas, 2015). A blank sample was used to correct the residual turbidity. The $\mathrm{pH}$ of milk samples was adjusted to 6.7 , and diluted 10 times before measurements. The results were expressed as $\mu \mathrm{mol}$ Trolox ${ }^{\circledR}$ equivalent per $\mathrm{mL}$ of milk sample $(\mu \mathrm{mol} \mathrm{TE} / \mathrm{mL}$ milk).

Malondialdehyde is the main product of oxidation of PUFAs. It is widely used as a marker of lipid peroxidation in food and biofluid. The MDA in milk was determined by its reaction with 2-thiobarbituric acid (TBA) (Sigma-Aldrich, St. Louis, USA) at $95^{\circ} \mathrm{C}$. MDA and TBA react together to produce a pink chromogen in an acid medium, which was measured photometrically at $532 \mathrm{~nm}$ using a spectrophotometer (UV-1201, 
Shimadzu, Japan). The standard curve to calculate the required concentration of MDA was obtained by acid hydrolysis of 1,1,3,3-tetramethoxypropane (Andrei et al., 2008).

The results of the analysis were compared by analysis of variance (ANOVA) with the diet as principal effect (SAS, Software Version 8.2. SAS Institute, Inc., Cary, NC). The ANOVA for milk production, feed efficiency, fatty acid profile, antioxidants, fat-soluble health lipid indices, TAC and MDA of milk included the main effect of the diet and week and the interaction between these two main effects. When the effect of diet was significant, the means were separated using Duncan's test. In addition, Pearson correlations were used to evaluate relationships between milk antioxidant activity (TAC values) and antioxidants fat-soluble, PUFA and levels of MDA. The level of significance to detect statistical differences was set at $P<0.05$ for all analyses.

\section{Results and Discussion}

Table 1 gives the composition and nutritional values of feeds. Hemp seeds contain $257 \mathrm{~g} / \mathrm{kg}$ crude protein (CP) and $316 \mathrm{~g} / \mathrm{kg}$ fat. The pressing process removes $63 \%$ of the fat, increasing the CP to $334 \mathrm{~g} / \mathrm{kg}$.

Hemp seed and hempseed cake contain, on average, $89.3 \%$ of UFA, of which $78.0 \%$ are PUFA (Table 2). Hemp seeds showed a substantial content of tocopherols (Table 2) which can ensure high oxidative stability in milk.

Table 1 Chemical composition and nutritional value of feeds

\begin{tabular}{|c|c|c|c|c|c|c|c|c|}
\hline \multirow{2}{*}{ Item } & \multirow{2}{*}{ DM, \% } & $\mathrm{CP}$ & Fat & NDF & ADF & PDIN $^{*}$ & PDIE & \multirow{2}{*}{$\begin{array}{l}\mathrm{NE}_{\mathrm{L}}, \mathrm{Mcal} \\
/ \mathrm{kg} \text { of } \mathrm{DM}\end{array}$} \\
\hline & & \multicolumn{6}{|c|}{$\mathrm{g} / \mathrm{kg}$ of $\mathrm{DM}$} & \\
\hline Grass hay & 88.7 & 92 & 15 & 538 & 315 & 69 & 83 & 0.96 \\
\hline Alfalfa hay & 90.3 & 178 & 26 & 422 & 318 & 114 & 96 & 1.12 \\
\hline Corn & 88.3 & 83 & 45 & 159 & 34 & 71 & 118 & 1.98 \\
\hline Barley & 87.2 & 112 & 21 & 307 & 122 & 76 & 104 & 1.61 \\
\hline Sunflower meal & 88.4 & 321 & 12 & 337 & 294 & 268 & 136 & 1.28 \\
\hline Hemp seed & 88.2 & 257 & 316 & 334 & 232 & 168 & 103 & 2.46 \\
\hline Hempseed cake & 89.4 & 334 & 117 & 436 & 362 & 205 & 108 & 1.82 \\
\hline
\end{tabular}

DM: dry matter; CP: crude protein; NDF: neutral detergent fibre; ADF: acid detergent fibre

"Calculated values (INRA, 1989). PDIN and PDIE: digestible CP in the intestine from microbial protein synthesis when availability of fermentable $\mathrm{N}$ in the rumen is limiting, and from microbial protein synthesis when availability of energy in the rumen is limiting, respectively

${ }^{* *} \mathrm{NE}_{\mathrm{L}}$ : net energy for lactation. The value of $\mathrm{NE}_{\mathrm{L}}$ was estimated according to INRA (1989)

Table 2 Major fatty acid composition of the lipid and tocopherol content of hemp seed and hempseed cake

\begin{tabular}{|c|c|c|}
\hline & HS & $\mathrm{HC}$ \\
\hline \multicolumn{3}{|l|}{ Fatty acid (\% of FAME) } \\
\hline C16:0 (palmitic acid) & $6.2 \pm 0.18$ & $9.3 \pm 0.21$ \\
\hline C18:0 (stearic acid) & $2.1 \pm 0.11$ & $3.8 \pm 0.10$ \\
\hline C18:1 n-9 (oleic acid) & $9.5 \pm 0.19$ & $13.1 \pm 0.27$ \\
\hline C18:2 n-6 (linoleic acid) & $56.1 \pm 1.04$ & $52.5 \pm 0.98$ \\
\hline C18:3 n-3 ( $\alpha$-linolenic acid) & $22.4 \pm 0.75$ & $19.1 \pm 0.37$ \\
\hline C18:3 n-6 ( $\mathrm{y}$-linolenic acid) & $3.7 \pm 0.14$ & $2.2 \pm 0.09$ \\
\hline \multicolumn{3}{|l|}{ Tocopherols (mg/100 g DM) } \\
\hline a-tocopherol & $4.16 \pm 0.24$ & $2.77 \pm 0.15$ \\
\hline$y$ - tocopherol & $60.85 \pm 1.58$ & $33.72 \pm 1.40$ \\
\hline$\delta$ - tocopherol & $3.11 \pm 0.17$ & $1.69 \pm 0.11$ \\
\hline
\end{tabular}


HS: hemp seed; HC: hempseed cake; Values are means $\pm \mathrm{SD}$, analysed individually in triplicate FAME: fatty acid methyl esters; DM: dry matter

The ingredients, chemical composition, and FA profile of the experimental diets are reported in Table 3. The higher DM intake in ewes fed cold-pressed hempseed cake compared with ewes fed hemp seed and the control diet (Table 3) shows that the higher NDF and ADF concentrations in the diets that included hempseed cake did not limit intake. The reasons are probably determined by the fact that NDF and ADF which originated from the concentrate (hempseed cake), has a low degree of rumen fill compared with NDF and ADF in roughages (Hessle et al., 2008).

Table 3 Ingredients, chemical composition, and fatty acids profile of the experimental diets

\begin{tabular}{|c|c|c|c|}
\hline \multirow{2}{*}{ Item } & \multicolumn{3}{|c|}{ Diets $^{*}$} \\
\hline & C & HS & $\mathrm{HC}$ \\
\hline \multicolumn{4}{|l|}{ Ingredient (kg/d per animal, as fed) } \\
\hline Grass hay & 0.900 & 0.900 & 0.900 \\
\hline Alfalfa hay & 0.500 & 0.500 & 0.500 \\
\hline \multicolumn{4}{|l|}{ Mixed meal: } \\
\hline - Corn & 0.35 & 0.07 & 0.23 \\
\hline - Barley & 0.13 & 0.32 & 0.05 \\
\hline - Sunflower meal & 0.34 & 0.25 & 0.06 \\
\hline - Hemp seed & - & 0.18 & - \\
\hline - Hempseed cake & - & - & 0.48 \\
\hline - Mineral mix & 0.03 & 0.03 & 0.03 \\
\hline Forage/concentrate ratio (reported of DM) & $60: 40$ & $60: 40$ & $60: 40$ \\
\hline \multicolumn{4}{|c|}{ Chemical composition (\% DM unless otherwise noted) } \\
\hline $\mathrm{DM}(\%)$ & 89.01 & 88.87 & 89.27 \\
\hline $\mathrm{CP}$ & 16.12 & 16.15 & 16.03 \\
\hline Ether extract & 2.21 & 4.51 & 4.50 \\
\hline NDF & 38.41 & 39.72 & 44.20 \\
\hline ADF & 22.80 & 23.14 & 25.02 \\
\hline $\mathrm{NE}_{\mathrm{L}}(\mathrm{Mcal} / \mathrm{kg} \mathrm{DM})^{* *}$ & 1.327 & 1.331 & 1.330 \\
\hline $\mathrm{DMl}(\mathrm{kg} / \mathrm{d})$ & 1.92 & 1.91 & 1.95 \\
\hline \multicolumn{4}{|l|}{ Major FA (\% of FAME) } \\
\hline C16:0 & 16.7 & 10.55 & 13.09 \\
\hline C18:0 & 3.29 & 4.33 & 4.46 \\
\hline C18:1 cis-9 & 22.58 & 21.47 & 23.31 \\
\hline C18:2 n-6 (LA) & 46.66 & 43.78 & 41.59 \\
\hline C18:3 n-3 (ALA) & 6.29 & 17.27 & 14.93 \\
\hline SFA & 22.55 & 16.51 & 18.07 \\
\hline MUFA & 25.42 & 22.67 & 23.82 \\
\hline PUFA & 52.03 & 60.82 & 58.11 \\
\hline LA : ALA & 7.42 & 2.53 & 2.78 \\
\hline
\end{tabular}

Diets: C: control diet; HS: diet containing $180 \mathrm{~g} / \mathrm{d}$ per head of hemp seed; HC: diet containing $480 \mathrm{~g} / \mathrm{d}$ per head of hempseed cake;

DM: dry matter; CP: crude protein; NDF: neutral detergent fibre; ADF: acid detergent fibre; NE $E_{L}$ : net energy for lactation. ${ }^{* *} T$ The value of $\mathrm{NE}_{\mathrm{L}}$ was estimated according to INRA (1989); DMI: dry matter intake

FA: fatty acid; FAME: fatty acid methyl esters;

SFA: saturated FA; MUFA: monounsaturated FA; PUFA: polyunsaturated FA; LA: linoleic acid; ALA: $\alpha$ - linolenic acid. 
Hemp had a significant effect on milk production. It increased milk yield, milk fat content, milk fat yield, ECM, FCM (6.5\%) and PCM (5.8\%) production, with no difference between hemp forms. Both forms of hemp tended to reduce milk lactose (Table 4). Similarly, Mughetti et al. (2012) investigated the effect of adding linseed to the diet of ewes on milk and observed increased milk yield and milk fat content.

Table 4 Effect of hemp seed or hemp seed cake on sheep milk production and composition

\begin{tabular}{|c|c|c|c|c|c|}
\hline \multirow{2}{*}{ Item } & \multicolumn{3}{|c|}{ Group ${ }^{1}$} & \multirow{2}{*}{$\mathrm{SEM}^{2}$} & \multirow{2}{*}{$\frac{p \text {-values }}{D^{3}}$} \\
\hline & C & HS & $\mathrm{HC}$ & & \\
\hline Milk yield (g/day) & $728^{b}$ & $781^{a}$ & $767^{\mathrm{a}}$ & 43.2 & * \\
\hline $\mathrm{ECM}^{4}$ (kg/day) & $0.751^{b}$ & $0.812^{\mathrm{a}}$ & $0.790^{\mathrm{a}}$ & 0.124 & ** \\
\hline $\operatorname{FPCM}^{5}$ (kg/day) & $0.784^{b}$ & $0.887^{\mathrm{a}}$ & $0862^{\mathrm{a}}$ & 0.112 & ** \\
\hline \multicolumn{6}{|l|}{ Milk composition (\%) } \\
\hline- Fat & $7.42^{b}$ & $8.12^{\mathrm{a}}$ & $7.97^{\mathrm{a}}$ & 0.043 & ** \\
\hline - Protein & 5.61 & 5.60 & 5.62 & 0.031 & ns \\
\hline - Lactose & $5.20^{\mathrm{a}}$ & $5.10^{\mathrm{ab}}$ & $4.85^{b}$ & 0.043 & * \\
\hline Fat yield (g/day) & $54.02^{b}$ & $63.42^{\mathrm{a}}$ & $61.13^{a}$ & 2.12 & ** \\
\hline Protein yield (g/day) & 40.84 & 43.74 & 43.12 & 1.97 & ns \\
\hline Lactose yield (g/day) & 37.86 & 39.83 & 37.20 & 5.21 & ns \\
\hline Feed efficiency (milk yield/DMI ${ }^{6}$ ) & $0.379^{b}$ & $0.409^{a}$ & $0.393^{\mathrm{ab}}$ & 0.028 & * \\
\hline
\end{tabular}

Means within a row with different superscripts are different $(P<0.05)$;

${ }^{1} \mathrm{C}$ : control diet, HS: diet containing hemp seed, HC: diet containing hempseed cake; ${ }^{2} \mathrm{SEM}$ : standard error of mean;

${ }^{3} \mathrm{D}$ : effect of experimental diet; ${ }^{4}$ Energy-corrected milk (ECM): milk yield $(\mathrm{kg} / \mathrm{d}) \times(0.071 \times$ fat $(\%)+0.043 \times \mathrm{CP}(\%)+0.2224)$;

${ }^{5}$ Fat- $(6.5 \%)$ and protein- $(5.8 \%)$ corrected milk (FPCM) $(4.38 \mathrm{MJ} / \mathrm{kg})=$ milk yield, $\mathrm{kg} \times(0.25+0.085 \times$ fat, $\%+0.035 \times$ protein,\%); ${ }^{6} \mathrm{DMl}$ : dry matter intake.

The possible explanation for the increase in milk yield that was observed in this study for HS and HC groups is the hemp amino acid (AA) composition, which was balanced for milk protein synthesis. Wang et al. (2008) reported a good AA profile of hemp protein, with a significantly higher proportion of essential AA to total AA, compared with soya protein, but a lower content of lysine and higher content of methionine.

The profiles of FAs and indices characterizing the quality of milk fat are presented in Tables 5 and 6 . The milk FA composition was altered significantly by the experimental diets (Table 5). The inclusion of hemp in the diets resulted in reduced total concentration of short chain FAs (SCFA) and middle chain FAs (MCFA) in the milk of ewes $(P<0.05)$. The total concentration of long chain FAs (LCFA) was lower in $C$ than the other groups $(P<0.01)$, following the increasing order of $\mathrm{C}, \mathrm{HS}$, and $\mathrm{HC}$. Compared with the seed form, the HC diet led to a substantial reduction in SCFA (12.35 versus $14.00 \%)$. This decrease may be related to a direct effect of LCFA, and decrease in plasma precursors, especially acetate (Hurtauad \& Peyraud, 2007).

The content of $\mathrm{C} 18: 0$ (stearic acid) decreased in HS and HC compared with $\mathrm{C}(P<0.05)$. The concentration of most of the C18:1, C18:2 and CLA isomers increased in the milk of sheep fed hemp compared with that of $\mathrm{C}(P<0.05)$. These results were expected as hemp seed and hempseed cake area are rich sources of $\mathrm{C} 18: 1, \mathrm{C} 18: 2$ and $\mathrm{C} 18: 3 \mathrm{FAs}$, and this was consistent with other works showing increased milk content of these FAs in ewes fed oilseed (Gómez-Cortés et al., 2009; Cieslak et al.,2010; Mierliță et al., 2011; Correddu, 2014; Buccioni et al., 2015; Correddu et al., 2016).

The presence of high concentrations of $\mathrm{C} 18: 1$ isomers in the HS and $\mathrm{HC}$ groups is probably the results of the ruminal biohydrogenation of C18:2 and C18:3 FA (Buccioni et al., 2015). The proportion of C18:1 t11 (VA) in the milk fat was remarkably enhanced $(P<0.001)$ to $4.38 \%$, and $5.08 \%$, corresponding to the feeding of $\mathrm{HS}$, and $\mathrm{HC}$, while in the control group it was only $2.53 \%$. This is consistent with the high amount of C18:3 n-3 supplied by dietary hemp, as this FA is a precursor of VA, which is produced by the ruminal metabolism and is in accordance with the works of Correddu et al. (2016), who found increased levels of VA in milk of dairy sheep fed linseed. VA is the precursor of $c 9, t 11$ CLA, formed by the $\Delta^{9}$ desaturase in mammary gland (Griinari \& Bauman, 1999). 
Table 5 Effect of hemp seed or hempseed cake on sheep milk fatty acid composition (\% of fatty acid methyl esters)

\begin{tabular}{|c|c|c|c|c|c|}
\hline \multirow{2}{*}{ Fatty acid } & \multicolumn{3}{|c|}{ Group ${ }^{1}$} & \multirow{2}{*}{ SEM $^{2}$} & \multirow{2}{*}{$\begin{array}{c}\text { p-values } \\
D^{3}\end{array}$} \\
\hline & C & HS & $\mathrm{HC}$ & & \\
\hline C4:0 - 8:0 & $5.87^{\mathrm{a}}$ & $5.91^{a}$ & $4.83^{\mathrm{b}}$ & 0.249 & * \\
\hline C10:0 & $9.21^{a}$ & $8.39^{b}$ & $7.52^{\mathrm{c}}$ & 0.392 & ** \\
\hline C12:0 & $4.88^{\mathrm{a}}$ & $4.27^{\mathrm{b}}$ & $3.81^{\mathrm{b}}$ & 0.176 & * \\
\hline C14:0 & $9.73^{\mathrm{a}}$ & $9.15^{\mathrm{b}}$ & $8.98^{\mathrm{b}}$ & 0.215 & * \\
\hline C14:1 & $0.14^{\mathrm{C}}$ & $0.59^{b}$ & $0.43^{\mathrm{a}}$ & 0.130 & $* * *$ \\
\hline C15:0 & 0.79 & 0.92 & 0.86 & 0.020 & ns \\
\hline C16:0 & $23.15^{\mathrm{a}}$ & $20.87^{b}$ & $20.73^{b}$ & 0.591 & * \\
\hline C16:1 & $0.51^{c}$ & $1.13^{b}$ & $1.68^{\mathrm{a}}$ & 0.071 & $* * *$ \\
\hline C17:0 & 0.50 & 0.58 & 0.53 & 0.034 & ns \\
\hline C17:1 & 0.47 & 0.51 & 0.50 & 0.124 & ns \\
\hline C18:0 & $11.12^{\mathrm{a}}$ & $10.24^{\mathrm{b}}$ & $9.79^{b}$ & 0.371 & * \\
\hline C18:1 trans-9 & $0.60^{\mathrm{b}}$ & $1.21^{\mathrm{a}}$ & $1.23^{\mathrm{a}}$ & 0.155 & * \\
\hline C18:1 trans-11 (VA) & $2.53^{\mathrm{c}}$ & $4.38^{\mathrm{b}}$ & $5.08^{\mathrm{a}}$ & 0.173 & $* * *$ \\
\hline C18:1 cis-9 & 22.77 & 21.37 & 21.51 & 0.728 & ns \\
\hline C18:1 cis-11 & $0.62^{\mathrm{b}}$ & $1.12^{\mathrm{a}}$ & $0.97^{\mathrm{a}}$ & 0.036 & * \\
\hline C18:2 trans-9, trans-12 & 1.35 & 1.35 & 0.91 & 0.030 & ns \\
\hline C18:2 n-6 (LA) & $2.08^{\mathrm{c}}$ & $2.49^{b}$ & $3.14^{\mathrm{a}}$ & 0.114 & * \\
\hline Total CLA & $1.18^{\mathrm{b}}$ & $2.39^{\mathrm{a}}$ & $2.81^{\mathrm{a}}$ & 0.050 & ** \\
\hline CLA cis-9, trans-11 (RA) & $1.07^{b}$ & $2.20^{\mathrm{a}}$ & $2.64^{\mathrm{a}}$ & 0.102 & ** \\
\hline CLA trans-10, cis-12 & $0.11^{b}$ & $0.19^{\mathrm{a}}$ & $0.17^{\mathrm{a}}$ & 0.041 & * \\
\hline C18:3 n-3 (ALA) & $1.53^{\mathrm{c}}$ & $2.54^{\mathrm{a}}$ & $2.28^{\mathrm{b}}$ & 0.067 & ** \\
\hline C18:3 n-6 & 0.17 & 0.09 & 0.10 & 0.020 & ns \\
\hline C20:0 & 0.33 & 0.31 & 0.35 & 0.051 & ns \\
\hline C20:4 n-6 & 0.21 & 0.19 & 0.20 & 0.030 & ns \\
\hline C20:5 n-3 (EPA) & $0.18^{\mathrm{b}}$ & $0.34^{\mathrm{a}}$ & $0.29^{\mathrm{a}}$ & 0.017 & * \\
\hline $\mathrm{C} 22: 6$ n-3 (DHA) & $0.28^{\mathrm{c}}$ & $0.46^{\mathrm{a}}$ & $0.37^{b}$ & 0.059 & * \\
\hline PUFA n-6 & 3.81 & 4.12 & 4.35 & 0.282 & ns \\
\hline PUFA n-3 & $1.99^{b}$ & $3.34^{\mathrm{a}}$ & $2.94^{\mathrm{a}}$ & 0.050 & $\star *$ \\
\hline Saturated FA & $65.58^{\mathrm{a}}$ & $60.64^{\mathrm{b}}$ & $57.50^{\mathrm{c}}$ & 2.410 & $* *$ \\
\hline Unsaturated FA & $34.42^{\mathrm{c}}$ & $39.36^{\mathrm{b}}$ & $41.50^{\mathrm{a}}$ & 1.783 & *** \\
\hline Monounsaturated FA & $27.44^{\mathrm{c}}$ & $29.51^{b}$ & $31.40^{\mathrm{a}}$ & 1.951 & * \\
\hline Polyunsaturated FA & $6.98^{\mathrm{b}}$ & $9.85^{\mathrm{a}}$ & $10.60^{\mathrm{a}}$ & 0.127 & $* * *$ \\
\hline Short chain FA (C4-C10) & $15.08^{\mathrm{a}}$ & $14.00^{\mathrm{b}}$ & $12.35^{\mathrm{c}}$ & 0.187 & * \\
\hline Middle chain FA (C12-C17) & $40.17^{\mathrm{a}}$ & $37.52^{b}$ & $37.53^{b}$ & 1.314 & * \\
\hline Long chain FA (C18-C22) & $44.75^{\mathrm{c}}$ & $48.48^{\mathrm{b}}$ & $50.12^{\mathrm{a}}$ & 2.030 & ** \\
\hline HFA & $37.76^{\mathrm{a}}$ & $34.79^{b}$ & $33.52^{b}$ & 1.511 & ** \\
\hline hFA & $33.30^{c}$ & $37.93^{b}$ & $39.89^{a}$ & 0.942 & ** \\
\hline
\end{tabular}

Means within a row with different superscripts are different $(P<0.05)$;

${ }^{1} \mathrm{C}$ : control diet, HS: diet containing hemp seed, HC: diet containing hempseed cake

${ }^{2}$ SEM: standard error of the mean; ${ }^{3} \mathrm{D}$ : effect of experimental diet

${ }^{4}$ FAME: fatty acid methyl esters; VA: vaccenic acid; LA: linoleic acid; ALA: linolenic acid; CLA: conjugated linoleic acid;

RA: rumenic acid; EPA: eicosapentaenoic acid; DHA: docosahexaenoic acid

HFA: hypercholesterolemic FA (C12:0 + C14:0 + C16:0); hFA: hypocholesterolemic FA (C18:1 + polyunsaturated FA); ns: $P>0.05 ;{ }^{*} P<0.05 ;{ }^{* *} P<0.01{ }^{* \star *} P<0.001$ 
In this study, the concentration of $c 9, t 11$ CLA in the milk of groups fed hemp (HS and HC) was higher $(P<0.05)$ than in those of $C$ group. The concentration of $c 9, t 11$ CLA in milk from the HS and HC groups (2.20-2.44\% of FAME) was comparable with that reported for sheep grazing high-quality pasture $(2.20 \%)$ (Nudda et al., 2005) or supplementation with linseed (2.33\%) (Gómez-Cortés et al., 2009), (2.16\%) (Correddu et al., 2016).

Milk ALA proportion was enhanced $66.01 \%$ by supplementing with hemp seed (group HS) and $49.02 \%$ by supplementing with hempseed cake (group $\mathrm{HC}$ ), relative to the control group $(P<0.01)$. This finding agrees with increased level of $\alpha$-linolenic acid in diets of ewes supplemented with hemp seed or hempseed cake. Hempseed cake is less efficient than whole raw seed in increasing milk ALA content. This is probably due to substantial hydrogenation of ALA in the rumen, especially under the HC diet, which provides available FA directly in the rumen fluid. The husk surrounding whole raw seeds would also have limited the total quantity of FA available to the body (Hurtauad \& Peyraud, 2007). Therefore, the hempseed cake-based diet tended to increase milk VA and CLA concentrations (total CLA and isomers $c 9, t 11$ CLA and $t 10, c 11$ CLA).

The inclusion of hemp seed or hempseed cake reduced the linoleic acid : linolenic acid ratio of the test diets from $7.4: 1$ in the control diet to 2.5-2.7 : 1 for the HS and HC diets (see Table 3) and produced significant shifts in the n-3 FA content of the milk lipids. For both the HS and the HC diets, the total n-3 FA content of the milk increased, and these increases were observed across the $n-3$ fatty acids that were measured: ALA, EPA and DHA. The intake of ALA appeared to be the primary determinant of the total $n-3$ FA content of milk lipids.

The concentration of LA was greater in the milk of the two groups fed hemp than in $\mathrm{C}(P<0.05)$. This is due to the high amount of LA in hemp seed and hempseed cake, in agreement with the findings of Mierliță (2016), which showed an increased level of this FA in milk of ewes fed hemp seed.

The total concentration of SFA decreased in the milk of the HS and HC groups compared with C, being lowest in $\mathrm{HC}(P<0.01)$. SFAs are derived mainly from ruminal microflora. The decrease in SFA in milk of HS and HC could be explained by the high amount of PUFAs, particularly LA and ALA, in hemp seed and hempseed cake, since PUFAs are reported to be toxic to the growth of ruminal microorganisms (Hurtauad \& Peyraud, 2007; Correddu, 2014).

Table 6 Effect of hemp seed or hempseed cake on health lipid indices in sheep milk

\begin{tabular}{|c|c|c|c|c|c|}
\hline & \multicolumn{3}{|c|}{ Group 1} & \multirow{2}{*}{ SEM $^{2}$} & \multirow{2}{*}{$\frac{\mathrm{p} \text {-values }}{\mathrm{D}^{3}}$} \\
\hline & C & HS & $\mathrm{HC}$ & & \\
\hline PUFA/SFA & $0.106^{\mathrm{b}}$ & $0.162^{\mathrm{a}}$ & $0.175^{a}$ & 0.002 & ** \\
\hline MUFA/SFA & $0.418^{b}$ & $0.486^{a}$ & $0.546^{\mathrm{a}}$ & 0.018 & * \\
\hline$n-6 / n-3 F A$ & $1.91^{\mathrm{b}}$ & $1.23^{\mathrm{a}}$ & $1.48^{\mathrm{a}}$ & 0.022 & ** \\
\hline HFA/UFA & $1.10^{\mathrm{a}}$ & $0.88^{\mathrm{b}}$ & $0.79^{b}$ & 0.031 & * \\
\hline $\mathrm{h} / \mathrm{H}$ & $0.88^{\mathrm{b}}$ & $1.09^{\mathrm{a}}$ & $1.29^{c}$ & 0.029 & * \\
\hline $\mathrm{Al}$ & $1.95^{\mathrm{a}}$ & $1.62^{\mathrm{b}}$ & $1.42^{\mathrm{c}}$ & 0.003 & ** \\
\hline TI & $1.76^{\mathrm{a}}$ & $1.28^{\mathrm{b}}$ & $1.22^{\mathrm{b}}$ & 0.027 & * \\
\hline LA/ALA & $1.36^{\mathrm{a}}$ & $0.98^{\mathrm{b}}$ & $1.12^{\mathrm{ab}}$ & 0.039 & * \\
\hline DI (18) & $70.45^{b}$ & $73.28^{\mathrm{a}}$ & $74.62^{\mathrm{a}}$ & 2.104 & ** \\
\hline DI $(18: 2 c 9, t 11)$ & $29.72^{b}$ & $33.43^{\mathrm{a}}$ & $32.44^{\mathrm{a}}$ & 0.591 & * \\
\hline
\end{tabular}

Means within a row with different superscripts are different $(P<0.05)$;

${ }^{1} \mathrm{C}$ : control diet, HS: diet containing hemp seed, HC: diet containing hempseed cake; ${ }^{2} \mathrm{SEM}$ : standard error of the mean

${ }^{3} \mathrm{D}$ : effect of experimental diet;

FA: fatty acid; SFA: saturated FA; UFA: unsaturated FA; MUFA: monounsaturated FA; PUFA: polyunsaturated FA; LA: linoleic acid; ALA: linolenic acid; HFA: hypercholesterolemic FA (C12:0 + C14:0 + C16:0);

$\mathrm{Al}$ (atherogenicity index) $=\mathrm{C} 12: 0+(\mathrm{C} 14: 0 \times 4)+\mathrm{C} 16: 0 / \mathrm{UFA}$

$\mathrm{TI}($ thrombogenicity index $)=(12: 0+16: 0+18: 0) /[(0.5 \times M U F A)+(0.5 \times n-6$ PUFA $)+(3 \times n-3$ PUFA $)+(n-3$ PUFA/n-6 PUFA $)]$, calculated according to Ulbricht \& Southgate (1991)

$\mathrm{h} / \mathrm{H}$ (hypocholesterolemic/Hypercholesterolemic $)=(\mathrm{C} 18: 1+\mathrm{PUFA}) /(\mathrm{C} 12: 0+\mathrm{C} 14: 0+\mathrm{C} 16: 0)$,

DI (18) $\left(\Delta^{9}\right.$-desaturase 18 index $)=100 \times[18: 1 /(18: 1+18: 0)]$,

DI $(18: 2 c 9, t 11): \Delta^{9}$-desaturase $(c 9, t 11 \mathrm{CLA})$ index $=100[c 9, t 11 \mathrm{CLA} /(c 9, t 11 \mathrm{CLA}+18: 1 t 11)]$; calculated according to

Pilarczyk et al. (2015); ns: $P>0.05$; ${ }^{\star} P<0.05$; ${ }^{\star *} P<0.01$; ${ }^{* \star} P<0.001$ 
The concentrations of de novo synthesized FAs (C12:0, C14:0 and C16:0) were lower in milk of groups receiving hemp than in those of the control group $(P<0.05)$. Among the SFAs, these three FAs are involved mainly in atherogenic and thrombogenic processes. The equations proposed by Ulbricht \& Southgate (1991) for the $\mathrm{Al}$ and $\mathrm{TI}$ showed that $\mathrm{C} 12: 0, \mathrm{C14}: 0$, and C16:0 FA are atherogenic while C14:0, C16:0, and C18:0 are thrombogenic. The n-3 FA, n-6 FA, and MUFA are anti-atherogenic and antithrombogenic. An increase in the $\mathrm{h} / \mathrm{H}$ ratio in milk fat has also been shown to beneficial to human health (Fernandez et al., 2007). As shown in Table 6, the inclusion of hemp seed and hempseed cake in the diet decreased both $\mathrm{Al}$ and $\mathrm{Tl}$ and the $\mathrm{h} / \mathrm{H}$ ratio increased compared with $\mathrm{C}(P<0.05)$. The current results agree with the findings of Correddu et al. (2016) and Cieslak et al. (2010), who recorded decreased values of Al and $\mathrm{TI}$ and increased $\mathrm{h} / \mathrm{H}$ when dairy ewes were fed linseed. The effect of dietary inclusion of hemp on these indices was probably related to the high rate of decrease in C12:0, C14:0, and C16:0 and increase in MUFA. The values of $\mathrm{Al}$ were lower and $\mathrm{h} / \mathrm{H}$ was higher in $\mathrm{HC}$ than $\mathrm{HS}(P<0.05)$, suggesting that the inclusion of hempseed cake appears to be more effective in ameliorating these indices than hemp seed.

The greater increase of the total n-3 FA $(P<0.01)$ led to a decrease in the ratio of n-6 to n-3 FA ( $P$ $<0.01)$ in the milk fat of the animals fed diets with hemp added (1.23 to 1.48) compared with the control animals (1.91). The extent of the change was greatest for the animals fed the HS diet.

The HS and HC groups showed higher values of desaturase indices (DI) C18 and CLA $(P<0.05)$ than the $\mathrm{C}$ group. An increasing activity of $\Delta^{9}$-desaturase is in agreement with the concentration of $c 9, t 11$ CLA increase with the inclusion of hemp in diets. The lower proportion of C18:0 in milk fat from ewes fed hemp could be ascribed to an incomplete ruminal biohydrogenation process in the rumen of either $\mathrm{C} 18: 3 \mathrm{n}-3$ or C18:1 to C18:0, resulting in increased milk C18:3 n-3, C18:1 isomers, and CLA isomers.

The TAC of milk samples determined by measuring the ABTS scavenging capacity is shown in Table 7. A high milk TAC corresponds to high oxidative stability of sheep milk. Significant differences were observed among the milks. In decreasing order, $\mathrm{HS}$ milk, $\mathrm{HC}$ milk and $\mathrm{C}$ milk showed the highest antioxidant activity. The increase of the antioxidant capacity in HS an HC milk samples might be related to higher concentration of $\alpha$-tocopherol, which is considered one of the most important fat-soluble antioxidants in milk.

Table 7 Effect of hemp seed or hempseed cake on lipophilic antioxidants content and oxidative stability of sheep milk

\begin{tabular}{|c|c|c|c|c|c|c|}
\hline & & \multicolumn{3}{|c|}{ Group 1} & \multirow{2}{*}{$\mathrm{SEM}^{2}$} & \multirow{2}{*}{$\frac{p \text {-values }}{D^{3}}$} \\
\hline & & C & HS & $\mathrm{HC}$ & & \\
\hline \multirow{2}{*}{ Vitamins ( $\mu \mathrm{g} / \mathrm{g}$ of fat milk) } & - a-tocopherol & $20.05^{\mathrm{b}}$ & $37.84^{\mathrm{a}}$ & $33.07^{\mathrm{a}}$ & 1.263 & ** \\
\hline & - all-trans-retinol & 8.17 & 10.43 & 9.39 & 0.781 & ns \\
\hline TAC ( $\mu \mathrm{mol}$ TE/ml milk) & & $18.12^{b}$ & $23.15^{\mathrm{a}}$ & $21.70^{\mathrm{ab}}$ & 0.598 & * \\
\hline MDA ( $\mu \mathrm{mol} / \mathrm{L}$ of milk) & & $4.02^{\mathrm{a}}$ & $2.87^{\mathrm{c}}$ & $3.25^{\mathrm{b}}$ & 0.192 & ** \\
\hline
\end{tabular}

Means within a row with different superscripts are different $(P<0.05)$;

${ }^{1} \mathrm{C}$ : control diet, HS: diet containing hemp seed, HC: diet containing hempseed cake; ${ }^{2} \mathrm{SEM}$ : standard error of mean;

${ }^{3} \mathrm{D}$ : effect of experimental diet;

TAC: total antioxidant capacity; TE: $\operatorname{Trolox}^{\circledR}$ equivalent; MDA: malondialdehyde

The oxidative process in milk depends on the PUFA content and on the balance between anti- and pro-oxidant compounds. The results obtained in determining TAC correlate with those obtained in the determination of lipid oxidative degradation. MDA, one of the compounds formed by peroxidation of UFAs, is frequently used as a marker of peroxidation (Andrei et al., 2014). The concentration of MDA was higher in milk samples from the control diet compared with HS and HC groups (Table 7). In the present study, the lowest MDA production in milk was found in the HS group. These ewes also had the highest mean $\alpha-$ tocopherol in milk, which could contribute to highest milk antioxidant activity. It seems that the drop of $\alpha$ tocopherol in milk to HC group could be due to decreased dietary antioxidant intake, notably tocopherols, which determined a higher concentration of MDA in milk compared with the HS group. The higher levels of tocopherol in milk fat for HS and HC groups might have positive implications in human nutrition as these substances, besides the protective PUFAs, reduce cholesterol oxidation, and therefore its cytotoxicity and atherogenicity (Bergamo et al., 2003). 
Subsequent analysis showed that milk MDA concentrations were positively correlated with PUFA concentrations $(r=0.617, P<0.001)$. In contrast, there was an inverse correlation between milk MDA concentrations and milk $\alpha$-tocopherol levels $(r=-0.541, P<0.01)$, and milk TAC levels $(r=-0.283, P<0.05)$ (Table 8). Similar results were reported by Vitas et al. (2012) for fermented milk products.

Table 8 Correlation between antioxidant activity, malondialdehyde, polyunsaturated fatty acids and fatsoluble antioxidants (tocopherol and retinol) in sheep milk

\begin{tabular}{llcc}
\hline Correlation & & Pearson's $(\mathbf{r})$ & $P^{\star}$ \\
\hline & MDA & -0.283 & $<0.05$ \\
TAC & PUFAs & 0.052 & 0.67 \\
& a-tocopherol & 0.468 & $<0.001$ \\
& all-trans-retinol & 0.165 & 0.29 \\
& PUFAs & & \\
& a-tocopherol & 0.617 & $<0.001$ \\
MDA & all-trans-retinol & -0.541 & $<0.01$ \\
& & -0.127 & 0.33 \\
\hline
\end{tabular}

TAC: total antioxidant capacity; MDA: malondialdehyde; PUFAs: polyunsaturated fatty acids;

${ }^{*} P$ value indicates the significance of the correlation

No association was found between the amount of retinol and the lower risk of lipid oxidation (lower concentration of MDA). Ewe milk, in contrast to that of cows, contains only retinol and no $\beta$-carotene, thus explaining differences in colour between bovine and small ruminant dairy products (Mierliță et al., 2017).

The results obtained in this study are somewhat confirmed by Hu et al. (2008), who reported that serum MDA concentration was decreased in rats fed on diets with hemp seed oil compared with control groups fed on diets containing soybean oil. Additionally, Konca et al. (2014), reported a decrease in the liver MDA concentration in laying Japanese quail, suggesting hemp seed has potential as a natural antioxidant.

\section{Conclusions}

The use of hemp in diets of ewes presented advantages in milk yield and composition, FA profile, and lipid oxidation. The hemp feeding increases the PUFA (especially $n-3$ and $c 9, t 11$ CLA) content of the milk, and contributes to reducing the $\mathrm{Al}, \mathrm{TI}$, and $\mathrm{n}-6 / \mathrm{n}-3 \mathrm{FA}$ ratio, and increases the $\mathrm{h} / \mathrm{H}$ ratio in milk fat and consequently may improve the nutritional quality of milk, which has potentially far-reaching human health benefits. The results obtained in this study suggest that the inclusion of hempseed cake appears to be more effective in improving the FA profile and health lipid indices than hemp seed. The high concentrations of PUFAs were associated with an increasing risk of lipid oxidation. The inclusion of hemp in the diet of ewes increased the $\alpha$-tocopherol content and antioxidant activity. These parameters revealed that hemp has good potential as a natural antioxidant and could contribute to preventing lipid oxidation in raw milk.

\section{Acknowledgements}

This research was conducted in the context of the project PN II - IDEI 679, sponsored by UEFISCDI-Romania. The author is also grateful to Rosbro Avicom SRL (Romania) for providing the experimental facilities and gifting hemp seed.

\section{Authors' Contributions}

Only the named author contributed to the study design, collection of data, analyses, interpretation of results and preparation of the paper.

\section{Conflict of Interest Declaration}

The author declares that there was no conflict of interest.

\section{References}

Andrei, S., Pintea, A. \& Bunea, A., 2008. Influence of processing methods on milk antioxidant activity (in ro). Scientific Papers USAMV 'Ion lonescu de la Brad' lasi, 51(10), 585-590. 
Andrei, S., Bunea, A. \& Pintea, A., 2014. Oxidative stress and natural antioxidants (in ro). Editura Academic Press, ClujNapoca, Romania.

AOAC, 1996. Official methods of analysis. Volume I. 16th ed. Association of Official Analytical Chemists, Arlington, VA., USA.

Bergamo, P., Fedele, E., lannibeli, L. \& Marzillo, G., 2003. Fat soluble vitamin contents and fatty acid composition in organic and conventional Italian dairy products. Food Chem. 82, 625-631.

Buccioni, A., Pauselli, M., Viti, C., Minieri, S., Pallara, G., Roscini, V., Rapaccini, S., Trabalza-Marinucci, M., Lupi, P., Conte, G. \& Mele, M., 2015. Milk fatty acid composition, rumen microbial population, and animal performances in response to diets rich in linoleic acid supplemented with chestnut or quebracho tannins in dairy ewes. J. Dairy Sci. $98,1145-1156$.

Cieslak, A., Kowalczyk, J., Czauderna, M., Potkanski, A. \& Szumacher-Strabel, M., 2010. Enhancing unsaturated fatty acids in ewe's milk by feeding rapeseed or linseed oil. Czech J. Anim. Sci. 55(11), 496-504.

Correddu, F., 2014. Utilization of grape seeds in ruminant nutrition: Effects of this by-product on health conditions, milk production and quality, and ruminal metabolism in Sarda dairy sheep. PhD thesis in Science and Biotechnology of Agricultural and Forestry Systems and Food Production, Zootechnical Sciences and Technologies, University of Sassari, 111-145.

Correddu, F., Gaspa, G., Pulina, G. \& Nudda, A., 2016. Grape seed and linseed, alone and in combination, enhance unsaturated fatty acids in the milk of Sarda dairy sheep. J. Dairy Sci. 99, 1725-1735.

Council Regulation (EC) No 1420/98 of 26 June 1998 amending Regulation (EEC) No 619/71 laying down general rules for granting aid for flax and hemp.

Dubois, V., Breton, S., Linder, M., Fanni, J. \& Parmentier, M., 2007. Fatty acid profiles of 80 vegetable oils with regard to their nutritional potential. Eur. J. Lipid Sci. Technol. 109, 710-732.

EU Council Directive, 2003. EU Council Directive no. 1782/ 2003. Official Journal of the European Communities, L270/52, 1920.

Fernandez, M., Ordonez, J.A., Cambero, I., Santos, C., Pin, C. \& de la Hoz, L., 2007. Fatty acid compositions of selected varieties of Spanish dry ham related to their nutritional implications. Food Chem. 101, 107-112.

Gibb, D.J., Shah, M.A., Mir, P.S. \& McAllister, T.A., 2005. Effect of full-fat hemp seed on performance and tissue fatty acids of feedlot cattle. Can. J. Anim. Sci. 85, 223-230.

Gómez-Cortés, P., Bach, A., Luna, P., Juárez, M. \& De la Fuente, M.A., 2009. Effects of extruded linseed supplementation on n-3 fatty acids and conjugated linoleic acid in milk and cheese from ewes. J. Dairy Sci. 92, 4122-4134.

Griinari, J.M. \& Bauman, D.E., 1999. Biosynthesis of conjugated linoleic acid its incorporation into meat and milk in ruminants. In: M.P. Yurawecz, M.M. Mossoba, J.K.G. Kramer, M.W Pariza \& G.J. Nelson (eds). Advances in conjugated linoleic acid research. Voume 1. AOCS Press, Champaign, IL, 180-200.

Havemose, M.S., Weisbjerg, M.R., Bredie, W.L.P., Poulsen, H.D. \& Nielsen J.H., 2006. Oxidative stability of milk influenced by fatty acids, antioxidants, and copper derived from feed. J. Dairy Sci. 89, 1970-1980.

Hessle, A., Eriksson, M., Nadeau, E., Turner, T. \& Johansson, B., 2008. Cold-pressed hempseed cake as a protein feed for growing cattle. Acta Agric. Scand. Sect. Anim. Sci. 58, 136-145.

$\mathrm{Hu}$, X.F., Li, Y., Wang, J., Song, X., \& Li, Y., 2008. Study on safety assessment and antioxidant function in serum of hempseed oil. Chin. J. Food Hygen. Abst. 5.

Hurtaud, C. \& Peyraud, J.L., 2007. Effects of feeding Camelina (seeds or meal) on milk fatty acid composition and butter spreadability. J. Dairy Sci. 90, 5134-5145.

INRA, 1989. Jarrige, R. \& Libbrey, J. (eds) Nutrition. Recommended allowances and feed tables. INRA, London \& Paris, 193-212.

ISO (International Organization for Standardization), 1978. Animal and vegetable fats and oils - Preparation of methyl esters of fatty acids. Method ISO 5509. ISO, Geneva, Switzerland.

ISO (International Organization for Standardization), 1999. Animal feeding stuffs. Determination of moisture and other volatile matter content. ISO, Geneva, Switzerland.

Konca, Y., Cimen, B., Yalcin, H., Kaliber, M. \& Beyzi S.B., 2014. Effect of hempseed (Cannabis sativa sp.) inclusion to the diet on performance, carcass and antioxidative activity in Japanese Quail (Coturnix coturnix japonica). Korean J. Food Sci. An. 34(2), 141-150.

Lin, C.F., Gray, J.I., Asghar, A., Buckley, D.J., Booren, A.M. \& Flegal, C.J., 1989. Effects of dietary oils and a-tocopherol supplementation on lipid composition and stability of broiler meat. J. Food Sci. 54(6), 1457-1484.

Mierliță, D., 2016. Fatty acid profile and health lipid indices in the raw milk of ewes grazing part-time and hemp seed supplementation of lactating ewes. S. Afr. J. Anim. Sci. 46(3), 237-246.

Mierliță, D., Daraban, St., Lup, F. \& Chereji, A., 2011. The effect of grazing management and camelina seed supplementation in the diet on milk performance and milk fatty acid composition of dairy ewes. J. Food Agric. Environ. 9 (3 \& 4), 368-373.

Mierliță, D., Pop, I.M., Teușdea, A., Lup, F., Dărăban, St., Georgescu, B., Boaru, A. \& Rahmann, G., 2017. Effect of forage preservation method on fatty acid composition and oxidative stability of organic sheep milk. Landbauforsch Appl. Agric. Forestry Res. 67(1), 43-52.

Mierliță, D. \& Vicas, S., 2015. Dietary effect of silage type and combination with camelina seed on milk fatty acid profile and antioxidant capacity of sheep milk. S. Afr. J. Anim. Sci. 45(1), 1-11.

Mihoc, M., Pop, G., Alexa, E. \& Radulov, I., 2012. Nutritive quality of Romanian hemp varieties (Cannabis sativa L.) with special focus on oil and metal contents of seeds. Chem. Cent. J. 6, 122-134. 
Mills, S., Ross, R.P., Hill, C., Fitzgerald, G.F. \& Stanton, C., 2011. Milk intelligence: Mining milk for bioactive substances associated with human health. Int. Dairy J. 21, 377-401.

Mughetti, L., Sinesio, F., Acuti, G., Antonini, C., Moneta, E., Peparaio, M. \& Trabalza-Marinucci, M., 2012. Integration of extruded linseed into dairy sheep diets: Effects on milk composition and quality and sensorial properties of Pecorino cheese. Anim. Feed Sci. Technol. 178, 27-39.

Murphy, J.J., Connolly, J.F. \& Mcneill, G.P., 1995. Effects on milk fat composition and cow performance of feeding concentrates containing full fat rapeseed and maize distillers grains on grass-silage based diets. Livest. Prod. Sci. 44(1), 1-11.

Nudda, A., McGuire, M.A., Battacone, G. \& Pulina, G., 2005. Seasonal variation in conjugated linoleic acid and vaccenic acid in milk fat of sheep and its transfer to cheese and ricotta. J. Dairy Sci. 88, 1311-1319.

Nudda, A., Battacone, G., Neto, O., Cannas, A., Francesconi, A., Atzori, A. \& Pulina, G., 2014. Feeding strategies to design the fatty acid profile of sheep milk and cheese. Invited review. R. Bras. Zootec. 43(8), 445-456.

Parker, T.D., Adams, D.A., Zhou, K., Harris, M. \& Yu, L., 2003. Fatty acid composition and oxidative stability of coldpressed edible seed oils. J. Food Sci. 68, 1240-1243.

Pilarczyk, R., Wójcik, J., Sablik, P. \& Czerniak, P., 2015. Fatty acid profile and health lipid indices in the raw milk of Simmental and Holstein-Friesian cows from an organic farm. S. Afr. J. Anim. Sci. 45, 30-38.

Puppel, K., Nałecz-Tarwacka, T., Kuczyńska, B., Gołebiewski, M., Kordysz, M. \& Grodzki, H., 2012. The age of cows as a factor shaping the antioxidant level during a nutritional experiment with oil and linseed supplementation for increasing the antioxidant value of milk. J. Sci. Food Agric. 92, 2494-2499.

SAS, 2001. SAS System for Microsoft Windows. Release 8.2. SAS Institute Inc., Cary, NC., USA.

Silversides, F.G. \& Lefrancois, M.R., 2005. The effect of feeding hemp seed meal to laying hens. Br. Poult. Sci. 46, 231235.

Simopoulos, A.P., 1991. Omega-3 fatty acids in health and disease and in growth and development. Am. J. Clin. Nutr. $54,438-463$.

Ulbricht, T.L.V. \& Southgate, D.A.T., 1991. Coronary heart disease: Seven dietary factors. Lancet 338, 985-992.

Van Soest P.J., Robertson, J.B. \& Lewis, B.A., 1991. Methods for dietary fiber, neutral detergent fiber, and non-starch polysaccharides in relation to animal nutrition. J. Dairy Sci. 74, 3583-3597.

Vitas, S.J., Malbasa, R.V., Grahovac, J.A. \& Loncar, E.S., 2012. The antioxidant activity of kombucha fermented milk products with stinging nettle and winter savory. Chem. Ind. Chem. Eng. Q. 19(1), 129-139.

Wang, X.S., Tang, C.H., Yang, X.Q. \& Gao, W.R., 2008. Characterization, amino acid composition and in vitro digestibility of hemp (Cannabis sativa L.) proteins. Food Chem. 107, 11-18.

Zhang, R.H., Mustafa, A.F. \& Zhao, X., 2006. Effects of feeding oilseeds rich in linoleic and linolenic fatty acids to lactating ewes on cheese yield and on fatty acid composition of milk and cheese. Anim. Feed Sci. Technol. 127, 220-233. 